\title{
Efektywność produkcji FAME na podstawie wymagań normy ISO 14045:2012
}

\section{Eco-efficiency of FAME production based on the requirements of ISO 14045:2012}

\author{
Michał Pajda ${ }^{1}$, Wojciech Mazela² \\ ${ }^{1}$ Instytut Nafty i Gazu - Państwowy Instytut Badawczy \\ ${ }^{2}$ BZK Sp. z o.o. i Wspólnicy Sp. K.
}

\begin{abstract}
STRESZCZENIE: Celem pracy było przedstawienie zagadnienia ekoefektywności, bazując na normie PN-EN ISO 14045:2012, w odniesieniu do procesu wytwarzania estrów metylowych kwasów tłuszczowych (FAME). Analiza ekoefektywności w doskonaleniu produktów i procesów/technologii uwzględnia jednocześnie aspekty ekonomiczne i środowiskowe. Ekoefektywność rozpatruje produkt i technologię w całym cyklu życia, od fazy budowy, poprzez użytkowanie, po likwidację. Oddziaływanie na środowisko naturalne ocenia się na podstawie: zużycia energii, materiałów, emisji zanieczyszczeń pyłowo-gazowych, odpadów i ścieków. Określając całkowite koszty, bierze się pod uwagę koszty produkcji, surowców, koszty na etapie użytkowania, łącznie z kosztami konserwacji, napraw i eksploatacji, a także utylizację lub recykling produktu. Analiza ekoefektywności jest pomocna w podejmowaniu decyzji dotyczących wyboru nowego produktu czy też projektowania nowej technologii i umożliwia wybór wariantu, który jest optymalny ekonomicznie i najmniej wpływa na środowisko. Zagadnienia te stają się szczególnie istotne w przypadku biopaliw, których szybki wzrost produkcji i polityka Unii Europejskiej, kładąca nacisk na stałe zwiększanie udziału energii ze źródeł odnawialnych, budzą jednocześnie obawy wielu ekspertów na całym świecie co do potencjalnych zagrożeń dla środowiska i bezpieczeństwa żywnościowego, związanych z produkcją biopaliw. W szczególności dąży się do minimalizacji ilości odpadów i pozostałości, wdrażając ideę gospodarki o obiegu zamkniętym. Takie podejście kreuje opracowywanie nowych technologii, które są bardziej przyjazne dla środowiska. Za sprawą regulacji podanych w dyrektywach RED i RED II istnieje szansa, że stosowane biopaliwa będą miały mniej negatywny wpływ na środowisko. Wynika to z obowiązku certyfikacji wykorzystywanych technologii według kryteriów zrównoważonego rozwoju, która jest prowadzona przez systemy dobrowolne uznane przez Komisję Europejską, takie jak np. System KZR INiG.
\end{abstract}

Słowa kluczowe: ekoefektywność, biopaliwa, FAME.

ABSTRACT: The aim of the work was to present the issue of eco-efficiency, based on the PN-EN ISO 14045:2012 standard in relation to the production of fatty acid methyl esters (FAME). The ecoefficiency analysis takes into account economic and environmental aspects in the improvement of products and processes / technologies. Eco-efficiency considers the product and technology throughout the life cycle, from the construction phase, through use to decommissioning. The impact on the natural environment is assessed on the basis of: consumption of energy, materials, dust and gas emissions, waste and sewage. Total costs include: production costs, raw material costs, costs during the use phase including maintenance, repair and operating costs, product disposal or recycling. The eco-efficiency analysis is helpful in making decisions regarding the selection of a new product or designing a new technology, and enables the selection of the variant that is the most economical and has the least possible impact on the natural environment. These issues are particularly important in the case of biofuels. The rapid growth of their production and the European Union's policy, which aims to increase the share of energy from renewable sources, cause concerns of many experts regarding the threats related to the production of biofuels, both for the environment and food security. In particular, efforts are made to minimize the amount of waste and residues by implementing the idea of a circular economy. This approach promotes the development of new technologies that are more environmentally friendly. Due to the regulations set out in the RED and RED II Directives, there is a chance that the biofuels will have a less negative impact on the environment. This results from the obligation to certify compliance with the sustainability criteria, which is carried out by voluntary systems recognized by the European Commission, such as the KZR INiG System.

Key words: eco-efficiency, biofuels, FAME

Autor do korespondencji: M. Pajda, e-mail:michal.pajda@inig.pl

Artykuł nadesłano do Redakcji: 27.10.2020 r. Zatwierdzono do druku: 03.03.2021 r. 


\section{Wprowadzenie}

Wzrost świadomości ekologicznej konsumentów oraz zaostrzające się uregulowania prawne w zakresie ochrony środowiska powodują zwiększenie wymagań odnośnie do jakości produkowanych wyrobów przy jednoczesnym dążeniu do zminimalizowania negatywnego oddziaływania na środowisko procesu ich wytwarzania. W szczególności zmierza się do minimalizacji ilości produkowanych odpadów i pozostałości, wdrażając ideę gospodarki o obiegu zamkniętym, również w obszarze produkcji biopaliw (Rogowska, 2018, 2019). Takie podejście kreuje opracowywanie nowych technologii, w tym technologii produkcji biopaliw. Za sprawą regulacji podanych w dyrektywie RED (Dyrektywa 2009/28/WE) i RED II (Dyrektywa 2018/2001) istnieje szansa, że stosowane biopaliwa będą miały mniej negatywny wpływ na środowisko. Wynika to z obowiązku certyfikacji na zgodność z kryteriami zrównoważonego rozwoju (Rogowska, 2014, 2015, 2017), która jest prowadzona przez systemy dobrowolne uznane przez Komisję Europejską. Takim systemem dobrowolnym jest KZR INiG, opracowany w Instytucie Nafty i Gazu - Państwowym Instytucie Badawczym (System KZR INiG). Jednak te regulacje nie obejmują wszystkich gałęzi przemysłu. Co więcej, przedsiębiorca, który planuje wdrożyć nową technologię, musi ją ocenić pod kątem zarówno efektu ekologicznego, jak i ekonomicznego, czyli ekoefektywności. Pojęcie ekoefektywności pojawiło się na początku lat dziewięćdziesiątych ubiegłego wieku (Czaplicka-Kolarz et al., 2010), jednak dopiero w dokumencie PN-EN ISO 14045:2012 po raz pierwszy w sposób znormalizowany ujęto zasady, wymagania i wytyczne do oceny ekoefektywności systemu wyrobu. Zgodnie ze wspomnianą normą ekoefektywność jest narzędziem, które umożliwia zintegrowaną ocenę wpływu na środowisko oraz ocenę ekonomiczną systemu wyrobu lub technologii, uwzględniając perspektywę cyklu życia. Przez wyrób rozumiany jest jakikolwiek produkt (w tym technologia) lub usługa. Natomiast system wyrobu jest to zbiór procesów jednostkowych połączony z przepływami elementarnymi i przepływami wyrobów wykonujący jedną lub więcej zdefiniowanych funkcji, który modeluje cykl życia wyrobu.

Kulczycka zaprezentowała koncepcję ekoefektywności i możliwość jej zastosowania do oceny projektów inwestycyjnych pod kątem modernizacji procesów wytwórczych i nowych, przyjaznych dla środowiska rozwiązań technologicznych (Kulczycka, 2013). W procesie podejmowania decyzji dotyczących oceny efektywności planowanych przedsięwzięć uwzględniono nie tylko uwarunkowania techniczne i ekonomiczne, lecz również środowiskowe i społeczne. Zagadnienia te są coraz częściej brane pod uwagę przez przedsiębiorstwa, które poszukują nowych źródeł przewagi konkurencyjnej. Możliwość wykorzystania koncepcji ekoefektywności w procesie zarządzania ekoinnowacjami przedstawiono w innej publikacji (Burchart-Korol et al., 2013b). Koncepcja ta może być traktowana jako wyznacznik innowacyjności i proekologicznego zarządzania we współczesnych przedsiębiorstwach, a także jako pierwszy krok w kierunku spełnienia zasad zrównoważonego rozwoju.

Ocena ekoefektywności znalazła już zastosowanie w takich branżach jak: przemysł wydobywczy (Salmi, 2007), przemysł stalowy (Kharel i Charmondusit, 2008; Van Caneghem et al., 2010), przemysł naftowy i petrochemiczny (Charmondusit and Keartpakpraek, 2011), gospodarka odpadami (Zhao et al., 2011), przemysł drzewny i papierniczy (Wang et al., 2011) oraz sprzęt elektroniczny i elektryczny (Aoe, 2007). W Polsce ocena ekoefektywności najczęściej analizowana była w odniesieniu do kopalni węgla kamiennego (Czaplicka-Kolarz et al., 2010; Burchart-Korol et al., 2013a; Krawczyk et al., 2014).

Do nielicznych prac ujmujących zagadnienie ekoefektywności w odniesieniu do produkcji biopaliw ciekłych należy praca kolumbijska (Castaneda et al., 2017), w której przedstawiono ocenę ekoefektywności w produkcji biodiesla z jatrofy przeczyszczającej, uprawianej dla oleju roślinnego, którego zawartość w jej nasionach osiąga 30-40\% (Jatrofa przeczyszczająca). Olej ten jest nieprzydatny do spożycia i może być stosowany wyłącznie do celów technicznych - wykorzystuje się go m.in. do produkcji biodiesla (Thapa et al., 2018). Autorzy przedstawili metodologię oceny cyklu życia, która została oparta na normach ISO 14040-14044. Ekoefektywność produkcji diesla z jatrofy została oceniona poprzez odniesienie do efektywności środowiskowej i opłacalności procesu. Stwierdzono, że produkcja biodiesla z jatrofy przeczyszczającej nie jest procesem o dużym potencjalnym wpływie na środowisko w porównaniu z innymi produktami, jednak z ekonomicznego punktu widzenia produkcja nie jest obecnie opłacalna, co wynika z wysokich kosztów materiału siewnego i ceny ropy naftowej.

Celem pracy włoskich autorów (Forleo et al., 2018) była ocena i porównanie zrównoważonych upraw rzepaku i słonecznika przeznaczonych do celów energetycznych. W ocenie ekoefektywności wzięto pod uwagę wyniki analiz środowiskowych i ekonomicznych na poziomie dwunastu gospodarstw. Stosując metodę attributional LCA, oceniono oddziaływanie na środowisko i wyznaczono ślad węglowy. Jako jednostkę funkcjonalną przyjęto 1 tonę gazów cieplarnianych emitowanych do atmosfery. Trzy gospodarstwa produkujące rzepak miały najniższą emisję GHG z całej próby. Stwierdzono, że praktyki intensywnego rolnictwa wyróżniające się wysokim poziomem nawożenia i mechanizacji mają negatywny wpływ na środowisko. Przy niskim poziomie wydajności ten wpływ jest jeszcze większy. Wyniki oceny ekoefektywności były korzystniejsze dla upraw rzepaku niż dla słonecznika. Ponadto wykonana ocena ekoefektywności uwidoczniła złożoność zagadnienia. Na wyniki wpływ miał rodzaj upraw i stosowane praktyki 
rolne w konkretnym gospodarstwie. Wyniki tego badania dostarczają cennych informacji zarówno pod względem środowiskowym, jak i ekonomicznym, są użyteczne przy podejmowaniu decyzji odnośnie do wyboru najkorzystniejszego wariantu, jeżeli chodzi o wybór roślin i stosowanych praktyk rolniczych.

\section{Ocena ekoefektywności zgodnie z normą PN-EN ISO 14045:2012}

Zgodnie z normą PN-EN ISO 14045:2012 przy podejmowaniu decyzji dotyczących planowania i przeprowadzania oceny ekoefektywności fundamentalne znaczenie mają następujące zagadnienia:

- ocena uwzględniająca cały cykl życia, od wydobycia i pozyskania surowca, poprzez produkcję energii i wytworzenie materiałów, użytkowanie, po procesy utylizacji i ostatecznego usunięcia;

- wykorzystanie na poszczególnych etapach analizy ekoefektywności wyników innych etapów oceny. Takie podejście przyczynia się do kompleksowości i spójności oceny ekoefektywności i przedstawianych wyników;

- przejrzystość analizy, umożliwiająca zapewnienie właściwej interpretacji wyników;

- kompleksowość, dzięki uwzględnieniu wszystkich atrybutów i aspektów środowiska i systemu wartości wyrobu;

- opieranie się na naukowych danych i metodologii oraz innych dowodach, a w przypadku ich niedostępności stosowanie konwencji międzynarodowych. Jeżeli nie istnieje żadna podstawa naukowa ani międzynarodowe konwencje, wówczas decyzje mogą opierać się na wyborach wartości.

Ocena ekoefektywności obejmuje następujące etapy:

- definicję celu i zakresu (w tym granice systemu, interpretację i ograniczenia);

- ocenę oddziaływania na środowisko;

- ocenę wartości systemu wyrobu;

- kwantyfikację ekoefektywności;

- interpretację (w tym analizę problemu jakości).

Fazy oceny ekoefektywności przedstawiono w sposób schematyczny na rysunku 1 (PN-EN ISO 14045:2012).

Ocena ekoefektywności to ocena efektywności środowiskowej systemu wyrobu w stosunku do jego wartości.
Ekoefektywność jest praktycznym narzędziem do równoległego zarządzania aspektami środowiskowymi i wartościowymi. Wynik oceny ekoefektywności odnosi się do systemu wyrobu, a nie do wyrobu jako takiego. Wyrób nie może być ekoefektywny, może taki być tylko system wyrobu, który obejmuje produkcję, stosowanie, usuwanie, tj. pełny cykl życia. Ponadto ekoefektywność to koncepcja względna, a system wyrobu jest bardziej lub mniej ekologiczny w stosunku do innego systemu wyrobu.

Przy określaniu celu należy rozważyć i wyraźnie opisać: cel oceny ekoefektywności, docelowych odbiorców oceny oraz zamierzone wykorzystanie wyników.

Natomiast przy określaniu zakresu należy wziąć pod uwagę i opisać następujące elementy: system wyrobu podlegający ocenie, funkcję i jednostkę funkcjonalną, granicę systemu wyrobu, alokacje do systemów zewnętrznych, metodę oceny środowiskowej i rodzaje oddziaływania, metodę oceny wartości i rodzaj wartości systemu wyrobu, wybór wskaźnika(-ów) efektywności, interpretację, która ma być stosowana, ograniczenia oraz raportowanie i przedstawianie wyników.

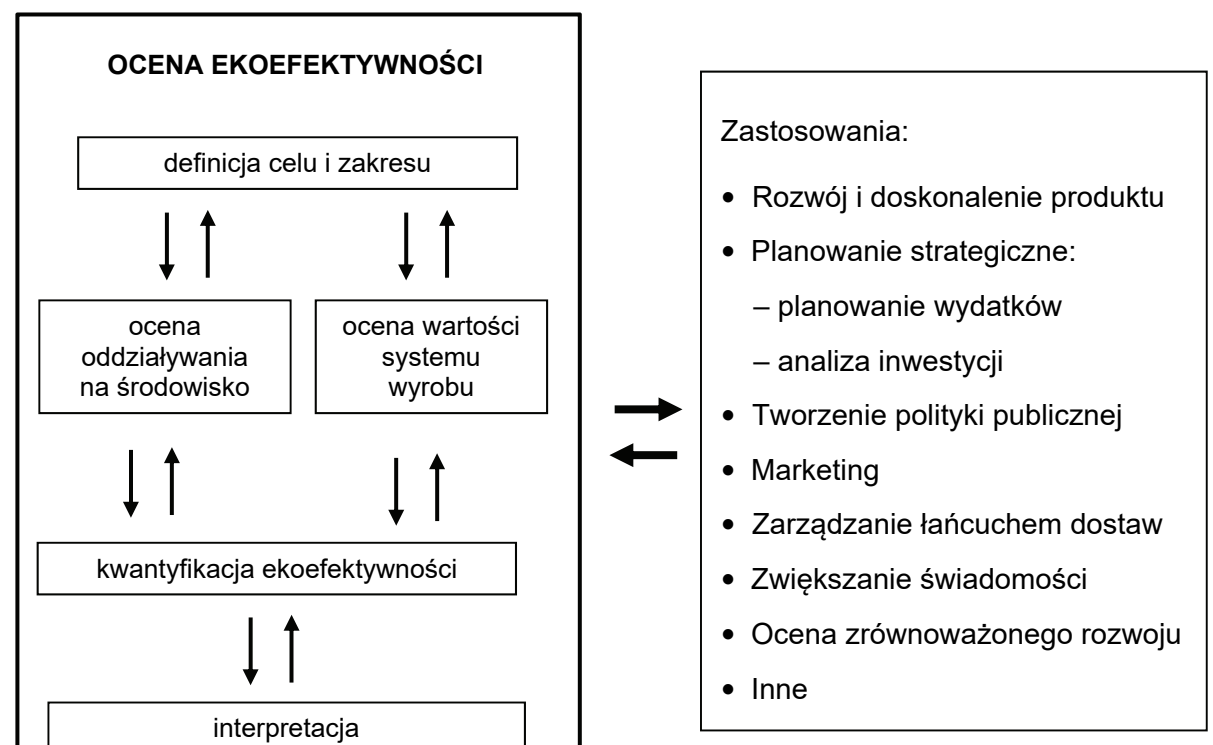

Rys. 1. Schemat oceny ekoefektywności

Fig. 1. Diagram of eco-efficiency assessment

\section{Zdefiniowanie celu i zakresu oceny}

Wykonanie oceny ekoefektywności w pierwszej kolejności wymaga scharakteryzowania obszaru przeprowadzanej analizy. Należy sprecyzować cel, podmiot, dla którego ta ocena jest wykonywana, i zamierzone wykorzystanie wyników tej oceny. Sa to kluczowe kwestie, których określenie ma wpływ na dalszą procedurę oceny. Do przeanalizowania oceny w kontekście otrzymywania FAME niezbędne jest więc dokonanie 
pewnych założeń, dlatego też przyjęty w pracy model może służyć jako przykład możliwego postępowania, nie zaś model uniwersalny.

Estry metylowe kwasów tłuszczowych (FAME), zwane również biodieslem, stanowią biokomponent oleju napędowego, paliwa do silników Diesla. Ich produkcja i zużycie w Polsce spośród wszystkich biopaliw są zdecydowanie największe. Mimo że estry mogą stanowić samodzielne paliwo (B100), obecnie wykorzystuje się je głównie w postaci domieszki do oleju napędowego wytwarzanego z ropy naftowej (zawartość biokomponentu do 7\% v/v) (Żółty i Krasodomski, 2017). W kilku krajach Europy Zachodniej (Austrii, Francji, Niemczech) oraz krajach skandynawskich estry są powszechnie stosowane od wielu lat, w Polsce rozwój tego kierunku zaznaczył się wyraźniej dopiero na początku 2008 roku. W tamtym czasie znacznie - prawie czterokrotnie w ujęciu rok do roku - wzrosła produkcja estrów z uwagi na wprowadzenie regulacji prawnych i ulgi akcyzowej dla wytwórców tego biokomponentu (Borychowski, 2012). Od tego czasu Polska na tle innych krajów europejskich odnotowuje relatywnie wysoki poziom produkcji FAME. W roku 2018 wytworzono w kraju ponad 850 tys. ton estrów metylowych sklasyfikowanych jako biokomponenty (BIP KOWR). Surowcami do produkcji FAME mogą być świeże tłuszcze roślinne (np. olej rzepakowy, słonecznikowy, sojowy czy palmowy), tłuszcze zwierzęce (Baranik i Łaczek, 2010) oraz tłuszcze odpadowe, np. zużyty olej kuchenny. Zgodnie z dyrektywą ILUC (Dyrektywa 2015/1513), zaimplementowaną do ustawodawstwa krajowego ustawą o biokomponentach i biopaliwach ciekłych (Ustawa z 25.08.2006 r.), biopaliwa wyprodukowane ze zużytego oleju kuchennego mogą być zaliczane podwójnie do Narodowego Celu Wskaźnikowego, nie mogą być natomiast zaliczane do celu dla biopaliw zaawansowanych.

Schemat wytwarzania FAME z rzepaku, będącego $\mathrm{w}$ warunkach polskich podstawowym surowcem, przedstawiono na rysunku 2. W przypadku produkcji FAME ocena ekoefektywności może być wykonana np. w celu porównania surowców, rozwiązań konstrukcyjnych instalacji czy też zwiększenia skali produkcji.

Opis granicy systemu należy wykonać zgodnie z ISO 14044. Granica systemu powinna być taka sama dla oceny środowiskowej, jak i dla oceny wartości systemu wyrobu. $\mathrm{W}$ analizowanym przypadku system wyrobu rozpoczyna się od momentu przygotowania gruntu pod uprawę rzepaku i kończy, gdy otrzymane FAME stają się komponentem do wytworzenia oleju napędowego lub też są surowcem do innych zastosowań (paliwo do celów opałowych w ekologicznych kotłach na biomasę, surowiec chemiczny do dalszej przeróbki, np. do otrzymywania związków powierzchniowo czynnych). W tej analizie wykluczono inne etapy cyklu życia, ponieważ nie są istotne z uwagi na zakres jej oceny.

\section{Ocena środowiskowa}

Ocena środowiskowa opiera się na ocenie cyklu życia zgodnie z ISO 14040 i ISO 14044. Wyniki oceny cyklu życia (LCI) mogą być bezpośrednio użyte jako dane wejściowe do oceny ekoefektywności. Na przykład tam, gdzie wykorzystanie zasobów i emisje pochodzą głównie z użycia kopaliny, przepływ ropy naftowej może być stosowany jako jedyny wkład środowiskowy. Jeżeli wykonywana jest ocena wpływu cyklu życia, musi być ona zgodna z ISO 14040 i ISO 14044.

Wskaźniki kategorii cyklu życia, jak określono zgodnie z ISO 14044, mogą być wykorzystywane do oceny ekoefektywności. Takie dane zazwyczaj prowadzą do profilu

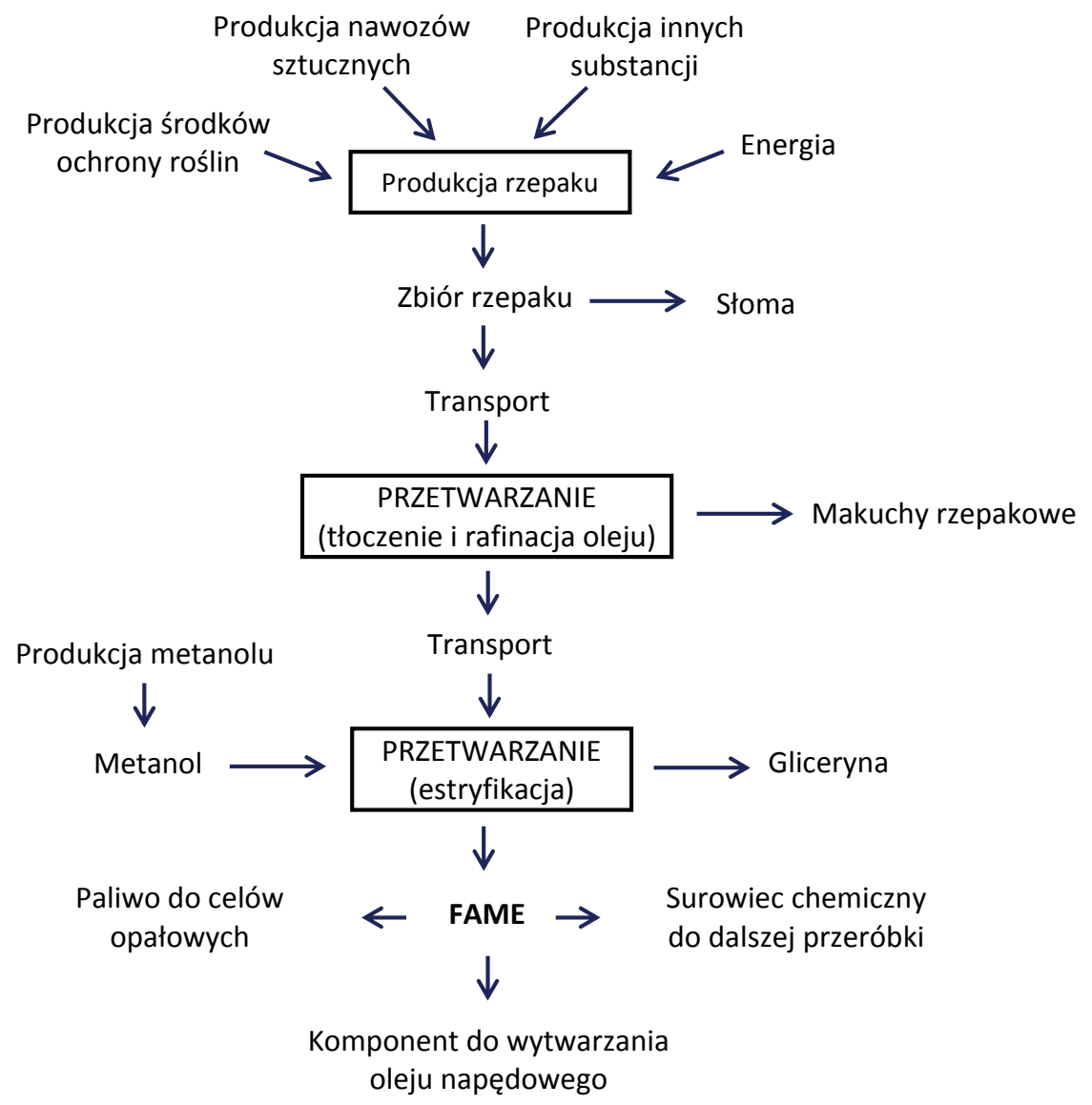

Rys. 2. Schemat wytwarzania FAME z rzepaku

Fig. 2. Diagram of FAME production from rapeseed 
ekoefektywności, w którym równolegle rozpatruje się kilka aspektów środowiskowych.

LCA (ang. life cycle assessment) składa się z czterech etapów: określenia celu i zakresu analiz, analizy zbioru danych wejściowych i wyjściowych (LCI - ang. life cycle inventory), oceny wpływu (LCIA - ang. life cycle impact assessment) oraz interpretacji. Wynikiem analizy techniką LCA jest określenie wpływu produktu/technologii na środowisko w całym cyklu życia. Ocena cyklu życia LCA umożliwia uwzględnienie aspektów środowiskowych we wszystkich fazach cyklu życia produktu lub technologii - od pozyskania surowców, poprzez fazę produkcji, transportu i użytkowania, aż po likwidację. Technika LCA, jako składowa ekoefektywności, umożliwia ocenę technologii/produktu między innymi na podstawie takich wskaźników środowiskowych jak:

- wpływ na zdrowie ludzkie, jakość ekosystemu, zużycie zasobów;

- emisje gazów cieplarnianych;

- skumulowane zużycie energii;

- wykorzystanie paliw kopalnych.

Do oceny i określenia mechanizmu środowiskowego można zastosować metodę Eco-indicator 99, która jest jedną z kilku metod używanych w analizie LCA. W metodzie tej znaczący nacisk kładziony jest na ocenę szkód. Uwzględnia ona trzy punkty końcowe kategorii: zdrowie ludzi, jakość ekosystemów i zasoby.

W przypadku otrzymywania FAME ze świeżych olejów roślinnych w szczególności należy przeanalizować oddziaływanie na środowisko na etapie uprawy roślin.

\section{Ocena wartości systemu wyrobu}

Ocena wartości systemu wyrobu powinna uwzględniać pełny cykl życia systemu wyrobu. Istnieje wiele sposobów oceny wartości systemu wyrobu, ponieważ system wyrobu może obejmować różne aspekty, w tym aspekty funkcjonalne, pieniężne i estetyczne. Wartość funkcjonalna systemu wyrobu odzwierciedla namacalne i wymierne korzyści dla użytkownika i innych zainteresowanych stron. W ocenie ekoefektywności wartość funkcjonalna różni się od jednostki funkcjonalnej. Wartość funkcjonalna powinna być zmierzona i powiązana z jednostką funkcjonalną w kwantyfikacji wydajności systemu wyrobu. Jednostka funkcjonalna zapewnia odniesienie, do którego dane wejściowe i wyjściowe są znormalizowane (w sensie matematycznym). Dlatego w ramach oceny ekoefektywności wartość funkcjonalna może ulec zmianie, np. ze względu na poprawę produktu, podczas gdy jednostka funkcjonalna pozostaje taka sama. Wartość pieniężna może być wyrażona w kategoriach kosztów, ceny, gotowości do zapłaty, wartości dodanej, zysku, przyszłych inwestycji itd. Inne wartości mogą obejmować wartości niematerialne, takie jak walory estetyczne, markę, wartości kulturowe i historyczne. Wartości te można określić za pomocą wywiadów, ankiet, badań rynkowych itp.

Ilościowe ujęcie wartości systemu wyrobu jest przeprowadzane przy użyciu odpowiednich wskaźników wartości wyrobu, zgodnie z celem i zakresem badania ekoefektywności.

Aspekty ekonomiczne produkcji biopaliw z rzepaku w Polsce przedstawili m.in. Gugała i współautorzy (2013), przeprowadzając analizę ekonomiczną przetworzenia rzepaku na biopaliwo, wykorzystywane do celów własnych gospodarstwa. Jak zaznaczyli autorzy, jednoznaczna ocena ekonomicznych, ekologicznych i technicznych aspektów stosowania biopaliw do zasilania silników Diesla jest uwarunkowana wieloma czynnikami. W pracy także wykazano, że o koszcie produkcji oleju decyduje przede wszystkim cena zakupu nasion rzepaku. Analogiczne wyniki przedstawiono również we wcześniejszych pracach (Dzieniszewski, 2009; Bieniek et al., 2010), w których również stwierdzono, że o koszcie wytwarzania biopaliwa decyduje w przeważającej części cena surowca, która to z kolei w głównej mierze zależy od stosowanej technologii oraz systemów dotacji dla rolnictwa. Zdaniem Bieńka i współautorów (2010) największy wpływ na opłacalność produkcji biopaliw mają dwa czynniki: cena rynkowa oleju napędowego oraz koszt produkcji nasion rzepaku, a w konsekwencji cena oleju rzepakowego.

\section{Ilościowe określenie ekoefektywności}

W celu wykonania obliczeń ekoefektywności należy określić poziomy ważności oddziaływania na środowisko dla poszczególnych czynników, czyli należy szczegółowo wskazać rodzaj i stopień szkodliwości danego rodzaju oddziaływania. Do oceny ważności niezbędna jest pojedyncza wartość współczynnika możliwa do określenia. Mimo że dotychczas opracowano szereg metod, nadal są one kontrowersyjne i nie ma metody powszechnie zaakceptowanej. Dobrze udokumentowane i dość powszechnie stosowane to: metoda ekopunktów (eco-points), metoda EPS (environmental priority system oraz metoda ekowskaźników (eco-indicator).

Wyniki ekoefektywności określa się, odnosząc wyniki oceny środowiskowej do wyników oceny wartości systemu wyrobu, zgodnie z określonymi definicjami celu i zakresu. Wskaźnik ekoefektywności zdefiniowano jako stosunek wskaźnika wartości wyrobu do wskaźnika oddziaływania na środowisko.

Wskaźnik ekoefektywności należy obliczyć według wzoru (1), natomiast współczynnik według wzoru (2). 
Ekoefektywność $=\frac{\text { Wartość wyrobu }}{\text { Oddziaływanie na środowisko }}$

Współczynnik $=\frac{\text { Ekoefektywnosć ocenianego wyrobu }}{\text { Ekoefektywność wyrobu bazowego }}$

\section{(1)}

- praca INiG - PIB na zlecenie MNiSW; nr zlecenia: 0092/

TP/2018, nr archiwalny: DK 4100-0084/2018.

\section{Literatura}

\section{Interpretacja i przedstawianie wyników}

Faza interpretacji oceny ekoefektywności obejmuje następujące elementy, zgodnie z przyjętym zakresem i celem badania: - identyfikację istotnych problemów na podstawie wyników faz oceny środowiskowej i oceny wartości systemu wyrobu; - ocenę uwzględniającą aspekty kompetencji, czułości, niepewności i spójności;

- formułowanie wniosków, ograniczeń i zaleceń.

\section{Podsumowanie}

Zagadnienia dotyczące ekoefektywności stają się istotnym czynnikiem branym pod uwagę przez inwestorów, producentów $\mathrm{i}$ innych interesariuszy, są one również istotne ze względu na coraz bardziej rygorystyczne wymagania dotyczące emisji gazów cieplarnianych podczas produkcji biopaliw na cele transportowe, wskazane w dyrektywie RED oraz dyrektywie RED II, która będzie obowiązywać od 2021 roku (Dyrektywa 2018/2001).

Wyniki oceny ekoefektywności powinny być przedstawiane zgodnie $\mathrm{z}$ założeniami przyjętymi w fazie określania celów i zakresu badania. Ze względu na złożoność oceny ekoefektywności - założenia, użyte dane, metody, ograniczenia oraz wyniki i wnioski oceny ekoefektywności powinny być przedstawiane z zachowaniem niezbędnej szczegółowości i przejrzystości, pozwalających docelowemu odbiorcy na właściwą ocenę wyników analizy.

Wynik oceny ekoefektywności odnosi się do systemu wyrobu, a nie do wyrobu jako takiego. Wyrób nie może być ekoefektywny, może taki być tylko system wyrobu, który obejmuje produkcję, stosowanie, usuwanie, tj. pełny cykl życia. Ponadto ekoefektywność jest koncepcją względną, a system wyrobu jest bardziej lub mniej ekologiczny w stosunku do innego systemu wyrobu.

Ocena ekoefektywności może być użyteczna w wielu aspektach dotyczących biopaliw, jak np. podczas podejmowania decyzji o zwiększeniu skali produkcji, budowie nowych instalacji, wdrożeniu w rafineriach co-processingu czy produkcji paliw zaawansowanych.

Artykuł powstał na podstawie pracy statutowej pt. Ocena ekoefektywności w produkcji biopaliw. Etap I-opracowanie modelu
Aoe T., 2007. Eco-efficiency and ecodesign in electrical and electronic products, Journal of Cleaner Production, 15(15): 1406-1414. DOI: 10.1016/J.JCLEPRO.2006.06.004.

Baranik M., Łaczek T., 2010. Właściwości niskotemperaturowe biopaliw zawierających estry metylowe kwasów thuszczowych, pochodzących z przeróbki tłuszczów zwierzęcych. Nafta-Gaz, 11: 1047-1058.

Bieniek J., Molendowski F., Kopa D., 2010. Analiza opłacalności produkcji estrów metylowych oleju rzepakowego na przykładzie wytwórni rolniczej W-400. Inżynieria Rolnicza, 1(119): 63-71.

BIP KOWR, http://bip.kowr.gov.pl (dostęp: wrzesień 2020).

Borychowski M., 2012. Produkcja i zużycie biopaliw płynnych w Polsce i na świecie - szanse, zagrożenia, kontrowersje. Roczniki Ekonomiczne Kujawsko-Pomorskiej Szkoły Wyższej w Bydgoszczy, 5: 39-59.

Burchart-Korol D., Krawczyk P., Śliwińska A., Czaplicka-Kolarz K., 2013a. Ocena ekoefektywności systemu produkcyjnego technologii naziemnego zgazowania węgla. Przemyst Chemiczny, 92(3): 384-390.

Burchart-Korol D., Kruczek M., Czaplicka-Kolarz K., 2013b. Wykorzystanie ekoefektywności w ocenie poziomu ekoinnowacyjności. [W:] Knosala R. (red.). Innowacje w zarządzaniu i inżynierii produkcji. Oficyna Wydawnicza Polskiego Towarzystwa Zarzadzania Produkcja, 286-297.

Castaneda I., Bojaca V., Ramos G., Santis A., Acevedo P., 2017. Study of the eco-efficiency of biodiesel production from the fruit of the jatropha curcas plant. Chemical Engineering Transactions, 58: 493-498. DOI: 10.3303/CET1758083.

Charmondusit K., Keartpakpraek K., 2011. Eco-efficiency Evaluation of the Petroleum and Petrochemical Group in the Map Ta Phut Industrial Estate, Thailand. Journal of Cleaner Production, 19 (2-3): 241-252. DOI: 10.1016/j.jclepro.2010.01.013.

Czaplicka-Kolarz K., Burchart-Korol D., Krawczyk P., 2010. Metodyka analizy ekoefektywności. Journal of Ecology and Health, 14: 267-271.

Dzieniszewski G., 2009. Wybrane aspekty ekologiczne i ekonomiczne zasilania silników Diesla paliwami roślinnymi. Inżynieria Rolnicza, 6(115): 45-52.

Forleo M.B., Palmieri N., Suardi A., Coaloa D., Pari L., 2018. The ecoefficiency of rapeseed and sunflower cultivation in Italy. Joining environmental and economic assessment. Journal of Cleaner Production, 172: 3138-3153. DOI: 10.1016/j.jclepro.2017.11.094.

Gugała M., Zarzecka K., Sikorska A., Stefaniak E., 2013. Aspekty ekonomiczne produkcji biopaliw z rzepaku. Roczniki Naukowe Stowarzyszenia Ekonomistów Rolnictwa i Agrobiznesu, 15(2): 97-100.

Jatrofa przeczyszczająca. $<$ https://pl.wikipedia.org/wiki/Jatrofa_przeczyszczająca $>$ (dostęp: wrzesień 2020).

Kharel G.P., Charmondusit K., 2008. Eco-efficiency evaluation of iron rod industry in Nepal. Journal of Cleaner Production, 16: 1379-1387. DOI: 10.1016/j.jclepro.2007.07.004.

Krawczyk P., Majer M., Krzemień J., 2014. Ocena możliwości zastosowania analizy kosztów i korzyści (CBA) do obliczania ekoefektywności kopalń węgla kamiennego w Polsce, Bezpieczeństwo Pracy i Ochrona Środowiska w Górnictwie, 6: 28-35.

Kulczycka J., 2013. Ekoefektywność w rozwoju i doskonaleniu organizacji. Prace Naukowe Uniwersytetu Ekonomicznego we Wrocławiu, Wydawnictwo Uniwersytetu Ekonomicznego we Wrocławiu, Wrocław, 277: 103-112. 
Rogowska D., 2014. Przegląd dobrowolnych systemów certyfikacji biopaliw na zgodność z kryteriami zrównoważonego rozwoju. Nafta-Gaz, 4: 256-261.

Rogowska D., 2015. The system of biofuels sustainability in Poland. Nafta-Gaz, 7: 487-493.

Rogowska D., 2017. Renewable materials as feedstock for energy production and other application. Nafta-Gaz, 10: 793-798. DOI: 10.18668/NG.2017.10.09.

Rogowska D., 2018. Produkcja biopaliw jako element gospodarki o obiegu zamkniętym, Nafta-Gaz, 2: 156-163. DOI: 10.18668/ NG.2018.02.10

Rogowska D., 2019. Modelowanie ścieżki produkcji FAME z alg pod kątem gospodarki o obiegu zamkniętym. Nafta-Gaz, 8: 494-504. DOI: $10.18668 / \mathrm{NG} .2019 .08 .07$

Salmi O., 2007. Eco-efficiency and industrial symbiosis a counterfactual analysis of a mining community. Journal of Cleaner Production, 15(17): 1696-1705. DOI: 10.1016/j. jclepro.2006.08.012.

System KZR INiG, http://www.kzr.inig.eu/pl/ (dostęp: wrzesień 2020).

Thapa S., Indrawan N., Bhoi P.R., 2018. An overview on fuel properties and prospects of Jatropha biodiesel as fuel for engines. Environmental Technology \& Innovation, 9: 210-219. DOI: 10.1016/j.eti.2017.12.003.

Van Caneghem J., Block C., Cramm P., Mortier R., Vandecasteele C., 2010. Improving eco-efficiency in the steel industry: The Arcelor Mittal Gent case. Journal of Cleaner Production, 18: 807-814. DOI: 10.1016/j.jclepro.2009.12.016.

Wang Y., Liu J., Hansson L., Zhang K., Wang R., 2011. Implementing stricter environmental regulation to enhance eco-efficiency and sustainability: a case study of Shandong Province's pulp and paper industry, China. Journal of Cleaner Production, 19: 303-310. DOI: 10.1016/j.jclepro.2010.11.006.

Zhao W., Huppes G., Voet E., 2011. Eco-efficiency for greenhouse gas emissions mitigation of municipal solid waste management: A case study of Tianjin, China. Waste Management, 31: 1407-1415. DOI: 10.1016/j.wasman.2011.01.013.

Żółty M., Krasodomski W., 2017. Stabilność oksydacyjna estrów metylowych kwasów thuszczowych stanowiących samoistne paliwo lub biokomponent olejów napędowych. Nafta-Gaz, 5: 399-405. DOI: $10.18668 / \mathrm{NG} .2018 .05 .08$

\section{Akta prawne i dokumenty normatywne}

Dyrektywa Parlamentu Europejskiego i Rady 2009/28/WE z dnia 23 kwietnia 2009 r. w sprawie promowania stosowania energii ze źródeł odnawialnych zmieniająca i w następstwie uchylająca dyrektywy 2001/77/WE oraz 2003/30/WE (Dz. Urz. UE L 140/16).

Dyrektywa Parlamentu Europejskiego i Rady (UE) 2015/1513 z dnia 9 września 2015 r. zmieniająca dyrektywę 98/70/WE odnoszącą się do jakości benzyny i olejów napędowych oraz zmieniająca dyrektywę 2009/28/WE w sprawie promowania stosowania energii ze źródeł odnawialnych (Dz. Urz. UE L 239/1 z 15.09.2015).

Dyrektywa Parlamentu Europejskiego i Rady (UE) 2018/2001 z dnia 11 grudnia $2018 \mathrm{r}$. w sprawie promowania stosowania energii ze źródeł odnawialnych (Dz. Urz. UE L 328/82).

PN-EN ISO 14045:2012 Zarządzanie środowiskowe - Ocena ekoefektywności systemów wyrobów - Zasady, wymagania i wytyczne.

Ustawa z dnia 25 sierpnia 2006 r. o biokomponentach i biopaliwach ciekłych (Dz.U. z 2006 r. nr 169, poz. 1199).

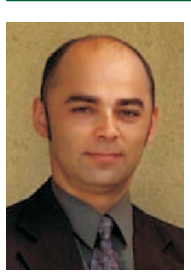

Dr inż. Michał PAJDA

Adiunkt w Zakładzie Paliw i Procesów Katalitycznych Audytor Systemu KZR INiG

Instytut Nafty i Gazu - Państwowy Instytut Badawczy ul. Lubicz 25 A

31-503 Kraków

E-mail: michal.pajda@inig.pl

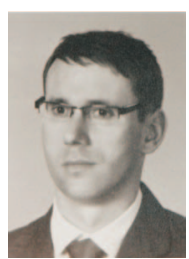

Dr inż. Wojciech MAZELA

Menedżer ds. Zrównoważonego Rozwoju

BZK Sp. z o.o. i Wspólnicy Sp. K.

ul. Połczyńska 97a, 01-303 Warszawa

E-mial: mazelaw@bzk.pl

Badania pochodzą z okresu, w którym p. Wojciech

Mazela był pracownikiem INiG - PIB 